Presented at the SPIE International Symposium on Optical Materials Technology for Energy Efficiency and Solar Energy Conversion XIII, April 18-22, 1994 in Friedrichsbau, Freiburg, Federal Republic of Germany, and published in the Proceedings.

\title{
Effect Of Switching Control Strategies On The Energy Performance Of Electrochromic Windows
}

\author{
R. Sullivan, E.S. Lee, K. Papamichael, M. Rubin, S. Selkowitz \\ Building Technologies Program \\ Energy and Environment Division \\ Lawrence Berkeley Laboratory \\ University of California \\ 1 Cyclotron Road \\ Berkeley CA 94720
}

April 1994

This work was supported by the Assistant Secretary for Energy Efficiency and Renewable Energy, Office of Building Technologies, Building Systems and Materials Division of the U.S. Department of Energy under Contract No. DE-AC03-76SF00098. 


\section{DISCLAIMER}

This report was prepared as an account of work sponsored by an agency of the United States Government. Neither the United States Government nor any agency thereof, nor any of their employees, make any warranty, express or implied, or assumes any legal liability or responsibility for the accuracy, completeness, or usefulness of any information, apparatus, product, or process disclosed, or represents that its use would not infringe privately owned rights. Reference herein to any specific commercial product, process, or service by trade name, trademark, manufacturer, or otherwise does not necessarily constitute or imply its endorsement, recommendation, or favoring by the United States Government or any agency thereof. The views and opinions of authors expressed herein do not necessarily state or reflect those of the United States Government or any agency thereof. 


\section{DISCLAIMER}

Portions of this document may be illegible in electronic image products. Images are produced from the best available original document. 


\title{
Effect Of Switching Control Strategies On The Energy Performance Of Electrochromic Windows
}

\author{
R. Sullivan, E.S. Lee, K. Papamichael, M. Rubin, S. Selkowitz \\ Energy and Environment Division \\ Lawrence Berkeley Laboratory \\ Berkeley, California 94720
}

\begin{abstract}
This paper presents the results of a study investigating the energy performance of electrochromic windows under a variety of state-switching control strategies. We used the DOE-2.1E energy simulation program to analyze the annual cooling, lighting, and total electricity use and peak demand as a function of glazing type, size, and electrochromic control strategy. We simulated a prototypical commercial office building module located in the cooling-dominated location of Blythe, California. Control strategies analyzed were based on daylight illuminance, incident total solar radiation, and space cooling load. Our results show that when a daylighting strategy is used to reduce electric lighting requirements, control algorithms based on daylight illuminance results in the best overall annual energy performance. If daylighting is not a design option, controls based on space cooling load yield the best performance through solar heat gain reduction. The performance of the incident total solar radiation control strategies varies as a function of the values of solar radiation which trigger the bleached and colored states of the electrochromic (setpoint range); for small to moderate window sizes which result in small to moderate solar gains, a large setpoint-range was best since it provides increased illuminance for daylighting without much cooling penalty; for larger window sizes, which provide adequate daylight, a smaller setpoint-range was best to reduce unwanted solar heat gains and the consequential increased cooling requirement. Of particular importance is the fact that reduction in peak electric demand was found to be independent of the type of control strategy used for electrochromic switching. This is because the electrochromics are generally in their most colored state under peak conditions, and the mechanism used for achieving such a state is not important.
\end{abstract}

\section{Introduction}

Electrochromic windows provide the opportunity to control and optimize the solar-optical energy performance in commercial buildings in much the same way as wavelength-selective glazings with controllable interior and exterior shading devices. Development of working prototype switchable glazings has progressed to the point that warrants a detailed analysis of the energy and peak demand performance of electrochromic windows using a variety of state-switching control strategies. In addition, recent major modifications to the DOE-2 hour-by-hour building energy simulation program (Ref. 1) now conveniently facilitates such an analysis.

Past simulation studies of electrochromic devices (Refs. 2, 3,4) have focused on the performance of glazings with hypothetical solar-optical properties in which switching occurred between transmitting to absorbing or transmitting to reflecting type glazings. For the absorptive glazing, the transmittance change between the bleached (high-transmittance) state and colored (lowtransmittance) state occurred throughout the entire solar spectrum. For the reflective glazing, the transmittance change between the bleached (high-transmittance) state and colored (lowtransmittance) state occurred only in visible portion of the solar spectrum with a constant high reflectance in the solar near-infrared. Daylight illuminance at a specific location in the space was used to control the electrochromic glazing properties. Results of these studies of idealized 
electrochromic glazings have shown the viability of using electrochromic windows in conjunction with lighting controls to reduce electric lighting and space cooling requirements.

We continue these energy simulation studies by reporting results based on absorptive and reflective electrochromic prototype devices currently being developed. The electrochromics were combined with clear and spectrally selective glazings. Results were obtained for electrochromic switching control strategies based on: (1) daylight illumination; (2) incident total solar radiation; and (3) space cooling load. In this paper, we limit our analysis to energy and electric demand issues. One of the most important benefits of "smart" windows is their ability to provide improved thermal and visual comfort, and other amenities such as privacy. These items will be explored in future studies.

\section{Model Description}

The performance of electrochromic windows was analyzed by completing hour-by-hour DOE-2 building energy simulations to evaluate the annual energy consumption and peak demand of a prototypical commercial office building module. The module consisted of a $100 \mathrm{ft}(30.5 \mathrm{~m})$ square core zone, surrounded by four identical perimeter zones, each $100 \mathrm{ft}$ by $15 \mathrm{ft}(30.5 \mathrm{~m}$ by $4.6 \mathrm{~m}$ ) facing four cardinal directions, Fig. 1. Each perimeter zone was divided into ten office spaces of equal size with a floor-to-floor height of $12 \mathrm{ft}(3.7 \mathrm{~m})$ and floor-to-ceiling height of $8.5 \mathrm{ft}$ $(2.6 \mathrm{~m})$. Each zone was assumed to have its own constant-volume variable-temperature HVAC system. The window-to-wall area ratio (window area expressed as a fraction of the floor-to-floor facade) was varied from 0.0 to 0.6 . This represents 0.0 to 0.85 of the floor-to-ceiling wall area. The maximum available overhead lighting was set to $1.5 \mathrm{~W} / \mathrm{ft}^{2}\left(16.1 \mathrm{~W} / \mathrm{m}^{2}\right)$.

Blythe, California, a cooling-dominated location, was selected for the simulations. Blythe is situated at a latitude of 33.6 degrees and longitude of 114.7 degrees and has $2280(1600)$ cooling degree days at a base temperature of $74 \mathrm{~F}(23.9 \mathrm{C})$ and 1300 (722) heating degree days at a base temperature of $65 \mathrm{~F}(18.3 \mathrm{C})$. We compared the performance of real clear and low-emissive (lowE) absorptive and reflective electrochromics currently being developed to an idealized highly reflective electrochromic achievable in the near future and to several conventional static glazings. The electrochromics are insulating glass units with an inner pane of either clear or low$\mathrm{E}$ glazing (coating on the gap surface) and an outer pane with the electrochromic layer on the gap surface.

For the absorbing electrochromic, the near-infrared absorptance increases in the colored state; for the reflecting electrochromic, the near-infrared reflectance increases in the colored state. The reflecting electrochromics have a somewhat lower shading coefficient for a given visible transmittance resulting from increased reflectance in the high end of the solar spectrum. The solar/optical/ thermal properties of the window prototypes are shown in Table 1. The idealized electrochromic is an insulating glass unit with an electrochromic coating on the inside surface of the outer pane and a reflective low-E glazing inner pane. It switches from transmitting to reflecting in the visible portion of the solar spectrum, while maintaining a minimum transmittance and a high reflectance in the near-infrared portion of the spectrum. We varied the solar/optical properties of the electrochromic windows using control strategies based on the following:

(1) Daylight Control: The visible transmittance of the window was linearly modulated between bleached (unswitched) and colored (fully switched) states in order to provide a daylight illuminance of $50 \mathrm{fc}(538 \mathrm{lux})$ at a reference point located $10 \mathrm{ft}(3.05 \mathrm{~m})$ deep along the center line of each perimeter office space. 
(2) Solar Control: The properties of the window were varied linearly as a function of the incident total solar radiation between low and high switching setpoints. The unswitched state was assumed for incident total solar radiation values less than or equal to $20 \mathrm{Btu} / \mathrm{hr}-\mathrm{ft}^{2}\left(63 \mathrm{~W} / \mathrm{m}^{2}\right)$. Three different values for the fully-switched state were examined; i.e., the fully-switched state was assumed for incident total solar radiation values greater than or equal to $60 \mathrm{Btu} / \mathrm{hr}-\mathrm{ft}^{2}(189$ $\left.\mathrm{W} / \mathrm{m}^{2}\right), 100 \mathrm{Btu} / \mathrm{hr}-\mathrm{ft}^{2}\left(315 \mathrm{~W} / \mathrm{m}^{2}\right)$, or $200 \mathrm{Btu} / \mathrm{hr}-\mathrm{ft} 2\left(630 \mathrm{~W} / \mathrm{m}^{2}\right)$.

(3) Space Load Control: The properties of the window changed between the unswitched and switched states based on the existence of a cooling load in the space during the previous hour. If a cooling load was not present during the previous hour, the electrochromic was set to its bleached (unswitched state); if a cooling load was present during the previous hour, the electrochromic was set to its colored (switched state).

The next part of this study discusses electrochromic performance using daylight control as a strategy and compares results to conventional glazings. Having established a performance base, we subsequently analyze other control strategy options.

\section{Electrochromic Energy Performance Using Daylight Control}

The objective in cooling-dominated locations is to reduce electricity use due to cooling by reducing the solar gain and the electricity use due to lighting by increasing the use of natural light. The tradeoffs between solar gain and lighting can be understood by analyzing the characteristics of west-facing perimeter zones. For example, Fig. 2 shows the annual cooling and lighting electricity use components in Blythe, California for a perimeter zone with west-facing idealized and real clear and low-E electrochromic windows as a function of window-to-wall ratio. Workplane illuminance was used to control the electrochromic system properties.

The importance of solar gain control is apparent through the large variation in cooling electricity use. The idealized device has a higher solar transmittance than the real devices in the bleached state, but a significantly lower solar transmittance than the real devices in the colored state. Since the electrochromics mostly operate close to the colored state when cooling is required, this results in lower cooling loads for the idealized device. There is a difference of approximately 2$3 \mathrm{kWh} / \mathrm{ft}^{2}\left(22-32 \mathrm{kWh} / \mathrm{m}^{2}\right)$ in cooling electricity between the real and idealized devices at the largest window-to-wall area ratio. This represents $24 \%-35 \%$ of the total (cooling+fan+lighting) electricity use one might expect from a west-facing perimeter zone without windows; i.e., 8.5 $\mathrm{kWh} / \mathrm{ft}^{2}\left(91 \mathrm{kWh} / \mathrm{m}^{2}\right)$. East-facing windows yield similar results; whereas, the difference for south-facing windows is $3.5-4.5 \mathrm{kWh} / \mathrm{ft}^{2}\left(38-48 \mathrm{kWh} / \mathrm{m}^{2}\right)$. For a north facing window with little incident direct solar radiation, it is about $0.4 \mathrm{kWh} / \mathrm{ft}^{2}\left(4.3 \mathrm{kWh} / \mathrm{m}^{2}\right)$.

As window-to-wall area ratio is increased, cooling performance for the real devices is similar regardless of the type of glazing and the overall absorptive or reflective properties. The largest performance difference between the clear-absorptive and low-E-reflective electrochromics is approximately $1 \mathrm{kWh} / \mathrm{ft}^{2}\left(11 \mathrm{kWh} / \mathrm{m}^{2}\right)$. Also, the larger difference in shading coefficients of the clear-absorptive and clear-reflective electrochromics, results in a greater difference $(0.6 \mathrm{kWh} / \mathrm{ft} 2$, $\left.6.4 \mathrm{kWh} / \mathrm{m}^{2}\right)$ than between the low-E-absorptive and low-E-reflective systems $(0.3 \mathrm{kWh} / \mathrm{ft} 2,3.2$ $\mathrm{kWh} / \mathrm{m}^{2}$ ). Among the real electrochromic devices, the low-E-reflective system provides the best control of solar gain.

Lighting electricity use tends to be the same for all electrochromic devices when using daylight control as seen on Fig. 2. This is because the visible transmittances of the electrochromic glazings vary to achieve the desired illuminance level of 50fc (538lux), thus the electric lighting requirements for the glazings will be similar. Daylight saturation (when the electric lighting is 
reduced to its minimum) occurs at window-to-wall ratios between 0.2 and 0.3 with a lighting reduction of close to $75 \%$ or $3 \mathrm{kWh} / \mathrm{ft}^{2}\left(32 \mathrm{kWh} / \mathrm{m}^{2}\right)$ at saturation.

The sum of the cooling and lighting electricity is also shown on Fig. 2. Differences in electrochromic performance are the same as for the cooling electricity use. However, we see that for window-to-wall ratios less than 0.5 , the real electrochromic devices result in less electricity use than perimeter zones that have no windows; i.e., a window-to-wall ratio of zero. This is a direct result of using natural light to reduce electric lighting requirements. The electricity use of the ideal electrochromic never exceeds that of a windowless wall, even for an all glass facade.

We present Fig. 3 to give an indication of electrochromic performance when compared to conventional glazings. Since cooling performance is proportional to transmitted solar gain, the tinted unit has the largest cooling requirement, followed by the low-E glazing, reflective glazing, and idealized electrochromic. For the largest window-to-wall area ratio in a west-facing orientation, there is a difference of $8 \mathrm{kWh} / \mathrm{ft}^{2}\left(86 \mathrm{kWh} / \mathrm{m}^{2}\right)$ between the idealized electrochromic and the tinted glazing. This reduces to about $2 \mathrm{kWh} / \mathrm{ft} 2\left(22 \mathrm{kWh} / \mathrm{m}^{2}\right)$ for the conventional reflective glazing. The real electrochromics (Fig. 2) have about the same level of cooling electricity use as reflective glazing. Lighting performance for the electrochromics is slightly better than the performance of conventional tinted or low- $\mathrm{E}$ windows. The conventional reflective glazing, with its low visible transmittance, has the smallest lighting energy reduction from daylighting. Real world experiments suggests that the daylighting benefits of conventional glazings are not often achieved since they are associated with glare and inconsistent window management based on the use of randomly operated shades or blinds. Automated control systems which reliably control thermal and visual comfort appear to be an important prerequisite for capturing available daylighting benefits.

Figure 4 shows peak electricity demand for the west-facing windows for the idealized and real electrochromics as well as the conventional glazings. Typically, peak demand for such a westfacing zone occurs during the summer months in the late afternoon. The relative peak performance for each of the glazings is very similar to the relative summed annual electricity use performance shown on Figs. 2 and 3 . There is a difference in peak electricity of about $2 \mathrm{~W} / \mathrm{ft} 2$ $\left(22 \mathrm{~W} / \mathrm{m}^{2}\right)$ between the real and idealized electrochromics. The peak demand of the conventional tinted glazing is about $5.4 \mathrm{~W} / \mathrm{ft}^{2}\left(58 \mathrm{~W} / \mathrm{m}^{2}\right)$ more than the idealized electrochromic. The real electrochromics peak values are similar to the reflective glazing values.

\section{Electrochromic Performance Using Other Control Strategies}

We now compare the previous results obtained with daylight control to other control strategies using either solar radiation or space load. When using solar control, the solar/optical properties of the electrochromic glazings varied linearly between the unswitched state for incident total solar radiation values of $20 \mathrm{Btu} / \mathrm{hr}-\mathrm{ft}^{2}\left(63 \mathrm{~W} / \mathrm{m}^{2}\right)$ and the fully-switched state for incident total solar radiation values of $60 \mathrm{Btu} / \mathrm{hr}_{\mathrm{ft}} 2\left(189 \mathrm{~W} / \mathrm{m}^{2}\right), 100 \mathrm{Btu} / \mathrm{hr}-\mathrm{ft}^{2}\left(315 \mathrm{~W} / \mathrm{m}^{2}\right)$, or $200 \mathrm{Btu} / \mathrm{hr}$ $\mathrm{ft}^{2}\left(630 \mathrm{~W} / \mathrm{m}^{2}\right)$. For space load control, on-off switching between the colored and bleached states was based on the existence of a space cooling load.

Figs. 5, 6, and 7 present the cooling and lighting electricity use components in Blythe, California for west facing idealized, real clear, and real low-E electrochromic windows, respectively, as a function of window-to-wall ratio for the various control strategies. For all glazings and window sizes, we see that daylight control provides the best overall performance. This implies that modulation of daylight also results in good solar control modulation as well. At the smaller values of window-to-wall area ratio (less than about 0.35 ), total electricity performance is more a function of lighting electricity decrease than cooling electricity increase. Therefore, the more daylight available from these window sizes, the better overall performance; i.e., control strategy 
performance follows the pattern: daylight control, solar control setpoints $20-200 \mathrm{Btu} / \mathrm{hr}-\mathrm{ft}^{2}$ (63$\left.630 \mathrm{~W} / \mathrm{m}^{2}\right)$, solar control setpoints $20-100 \mathrm{Btu} / \mathrm{hr}-\mathrm{ft}^{2}\left(63-315 \mathrm{~W} / \mathrm{m}^{2}\right)$, solar control setpoints 20 $60 \mathrm{Btu} / \mathrm{hr}-\mathrm{ft}^{2}\left(63-189 . \mathrm{W} / \mathrm{m}^{2}\right)$, and lastly space load control. At larger window-to-wall area ratios, the increase in associated solar gains causes an increase in cooling electricity use and the solar control setpoint strategies reverse their position; i.e., the $20-60 \mathrm{Btu} / \mathrm{hr}-\mathrm{ft}^{2}\left(63-189 \mathrm{~W} / \mathrm{m}^{2}\right)$ strategy performs better than the $20-200 \mathrm{Btu} / \mathrm{hr}-\mathrm{ft}^{2}\left(63-630 \mathrm{~W} / \mathrm{m}^{2}\right)$ strategy. The smaller setpoint range does a better job of minimizing solar heat gains. For a given window size, it should therefore be possible to develop a set of control algorithms that are sensitive to both lighting levels and solar heat gain and that work well under all climatic conditions.

The use of space cooling load as a control strategy results in the smallest cooling electricity, but also the smallest lighting electricity use reduction due to daylighting. In fact for the ideal electrochromic, Fig. 5, both cooling and lighting electricity use have almost no variation with window-to-wall area ratio when using space cooling load control; i.e., control of cooling approaches an optimum, but there is also no daylighting and thus the beneficial lighting aspects are negated. As a result, use of space cooling load results in the largest summed electricity use for all glazings modeled. Cooling load control, however, can be a preferable strategy for those building configurations that do not incorporate daylighting as an energy saving design option. It may also be an important strategy to minimize chiller size or to maintain comfort under conditions when a building HVAC is not able to provide its rated cooling output.

Peak electricity consumption for the different control strategies is presented on Fig. 8. For each glazing, the peaks are very similar for each strategy, since under peak conditions, the electrochromics are near their completely colored (switched) state. The largest difference in peak, $0.8 \mathrm{~W} / \mathrm{ft}^{2}\left(8.6 \mathrm{~W} / \mathrm{m}^{2}\right)$, due to control strategy variations occurs for the idealized electrochromic at a window-to-wall area ratio of 0.6. If further studies confirm that peak electricity use does not depend significantly on the selected control option, it would simplify the analysis of future electrochromic devices.

\section{Conclusions}

1. There is a small difference in the cooling performance of real clear and low-E absorptive and reflective electrochromic glazings. However, current reflective devices may have improved properties in the future and we show there is the potential of achieving further cooling reductions when using an idealized highly reflective electrochromic device.

2. The lighting performance of idealized and real electrochromics is the same when using daylight illuminance to control electrochromic switching. There is about a $75 \%$ reduction in lighting energy requirements at daylight saturation, which occurs at a window-to-wall ratio of about 0.25 .

3. The idealized highly reflective electrochromic significantly outperforms conventional glazings, both on an annual basis and under peak demand conditions. The cooling performance of currently available real electrochromics is about the same as conventional reflective glazings; however, the daylighting performance of the real electrochromics is much better. At low window-to-wall area ratios, the total energy performance of real electrochromics is about the same as static low-E tinted glazings; at high window-to-wall area ratios, real electrochromic total energy performance is the same as conventional reflective glazings.

4. Daylight control of electrochromic switching provides the best overall energy performance because of the large decrease in required lighting energy due to daylighting. If daylighting is not a design option, space cooling load control yields the best performance. Higher lighting power 
densities would further emphasize the importance of daylight control; lower power densities would shift the emphasis to solar heat gain control.

5. The setpoint range for incident total solar radiation control must be correlated with window size to achieve good performance. At smaller window-to-wall area ratios (less than 0.35), a large setpoint range is desirable to facilitate increased daylighting; at larger window-to-wall area ratios, a small setpoint range is desirable to facilitate solar gain control.

6. Peak electricity demand for electrochromic glazings analyzed is similar regardless of switching control strategy. Under peak conditions, the electrochromics are in switched states that have similar solar/optical properties and therefore the instantaneous performance is also similar.

7. One of the most important benefits of a dynamic electrochromic device is its ability to modulate light and heat to improve thermal comfort and reduce glare. The comfort issues associated with these strategies will be addressed in other studies.

\section{Future Studies}

Future studies of electrochromics will focus on the following items: (1) Additional control strategies such as incident direct solar radiation, transmitted total and direct solar radiation, space air temperature and variations in the scheduling and mixing of electrochromic control strategies. (2) Analysis of the thermal and visual comfort aspects of electrochromic glazings and comparison with more conventional type glazings. We have completed some preliminary work in this area, but correlation of comfort to specific electrochromic property variations must be documented. (3) Development of effective solar heat gain and visible transmittance parameters for electrochromic devices to give an indication of expected energy and comfort performance. This requires a statistical analysis of the hourly variation of the solar/optical properties of the electrochromic devices. (4) Simulation of electrochromic devices in heating-dominated geographic locations. (5) Continuing analysis of daylight illuminance as a control strategy using different reference points in the space.

\section{Acknowledgments}

The authors would like to express thanks to LBL researchers D. Hopkins and E. Finlayson for their contribution to this study. This work was supported by the Assistant Secretary for Energy Efficiency and Renewable Energy, Office of Building Technologies of the U.S. Department of Energy under Contract No. DE-AC03-76SF00098.

\section{References}

1. F.C. Winkelmann, B.E. Birdalll, W.F. Buhl, K.L. Ellington, and A.E. Erdem, "DOE-2 supplement: version 2.1E," Lawrence Berkeley Laboratory Report No. LBL-34947, November 1993..

2. E.S. Lee and S. Selkowitz. "The design and evaluation of integrated envelope and lighting control strategies for commercial buildings," submitted for publication in ASHRAE Transactions, January 1995 and draft Lawrence Berkeley Laboratory Report, March 1994.

3. J.L. Warner, M.S. Reilly, S.E. Selkowitz, D.K. Arasteh, and G.D. Ander. "Utility and economic benefits of electrochromic smart windows," Proceedings of the ACEEE 1992 Summer Study in Energy Efficiency, August 30-September 5, 1992 at Asilomar Conference Center, Pacific Grove, CA and Lawrence Berkeley Laboratory Report No. LBL-32638, June 1992. 
4. S. Reilly, D. Arasteh, and S. Selkowitz. "Thermal and optical analysis of switchable window glazings," Solar Energy Materials 22, pp. 1-14, 1991 and Lawrence Berkeley Laboratory Report No. LBL-29629, August 1990.

TABLE 1

Window Solar/Optical/Thermal Properties

PROTOTYPE

Electrochromic Glazings

Clear Absorptive

Clear Reflective

Low-E Absorptive

Low-E Reflective

Idealized

Conventional Glazings

Tinted Grey

Reflective Clear

Low-E Tint
SC: Shading

Coefficient

Bleached/Colored

$.85 / .21$

$.73 / .20$

$.57 / .18$

$.54 / .18$

$.67 / .06$

.54

.20

.35
Tvis: Visible

Transmittance

Bleached/Colored

$.76 / .14$

$.73 / .14$

$.66 / .10$

$.64 / .12$

$.65 / .00$

.38

.13

.41
Tris/SC

Bleached/Colored

U-Factor

$\mathrm{Btu} / \mathrm{hr}-\mathrm{ft} 2 \mathrm{~F}$

$\left(\mathrm{W} / \mathrm{m}^{2}-\mathrm{K}\right)$

$.89 / .67$

$1.00 / .70$

$.43(2.47)$

$1.29 / .56$

$1.19 / .67$

$.97 / .00$

$.43(2.47)$

$.41(2.35)$

$.41(2.35)$

$.42(2.40)$

.70

.65

1.17
$.51(2.88)$

$.43(2.45)$

$.42(2.37)$

NOTE: Center-of-glass U-Factors under ASHRAE summer conditions; 89F (31.6C) outdoor air and $75 \mathrm{~F}(23.8 \mathrm{C})$ indoor air temperature, with $7.5 \mathrm{mph}(12.1 \mathrm{~km} / \mathrm{h})$ outdoor air velocity and 248.2 $\mathrm{Btu} / \mathrm{hr}-\mathrm{ft} 2(781.8 \mathrm{~W} / \mathrm{m} 2)$ direct solar radiation. 


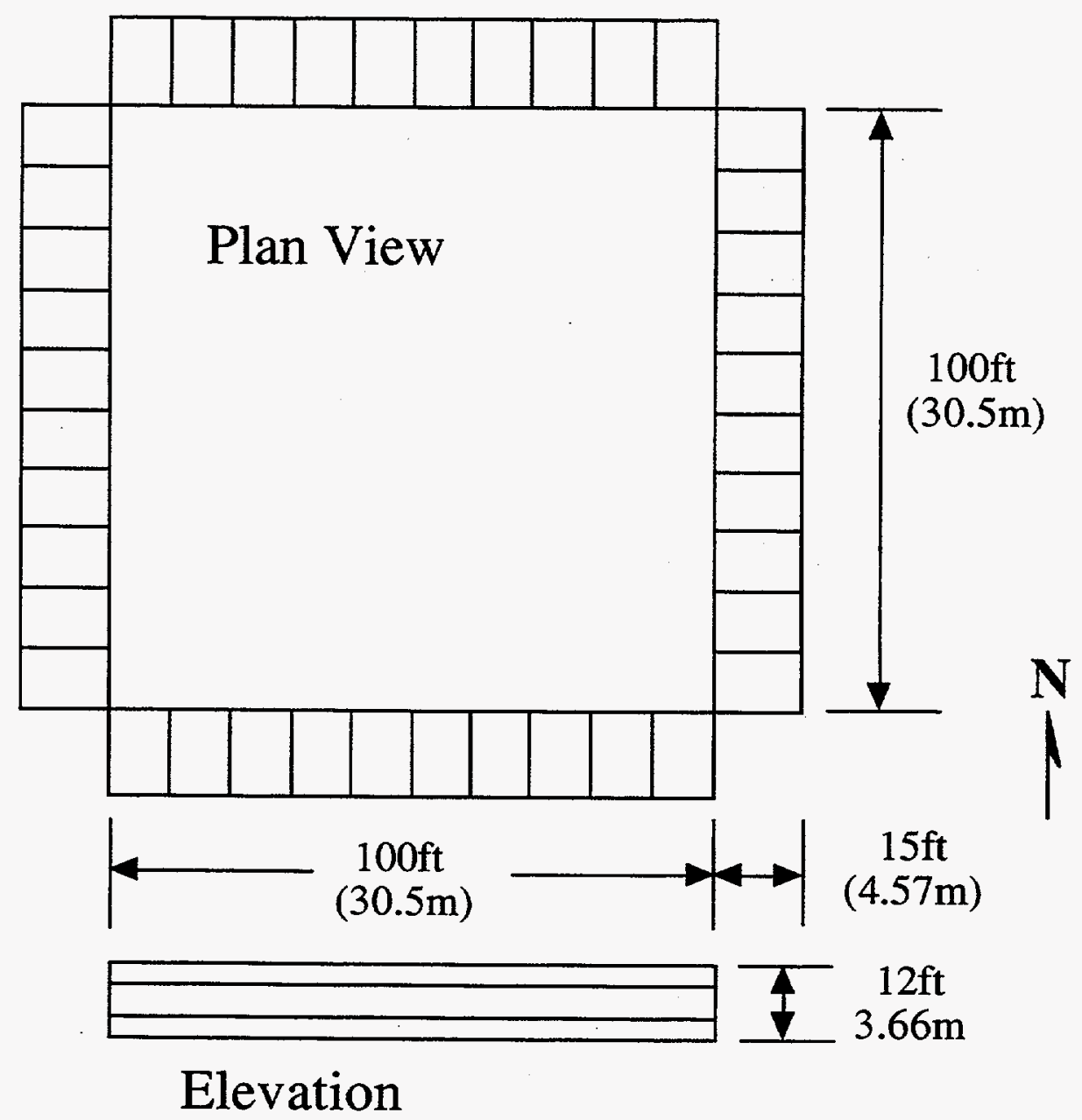

Figure 1: Commercial office building module used in the annual simulations. 


\section{Cooling + Fan \\ Electricity}

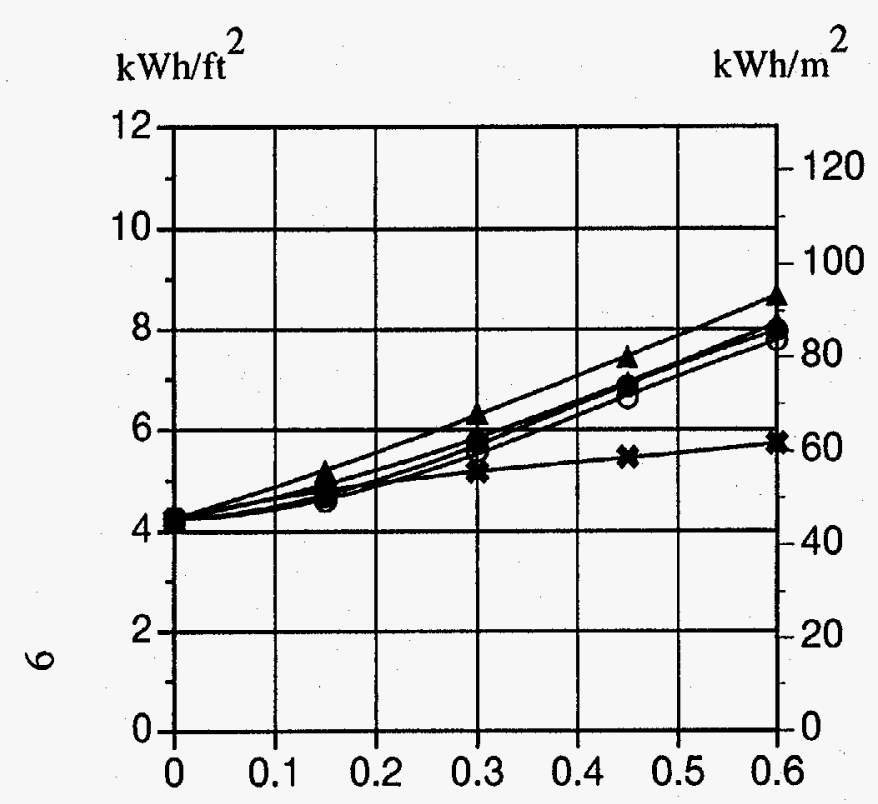

Window-to-Wall Ratio
Lighting Electricity
Cooling + Fan + Lighting Electricity

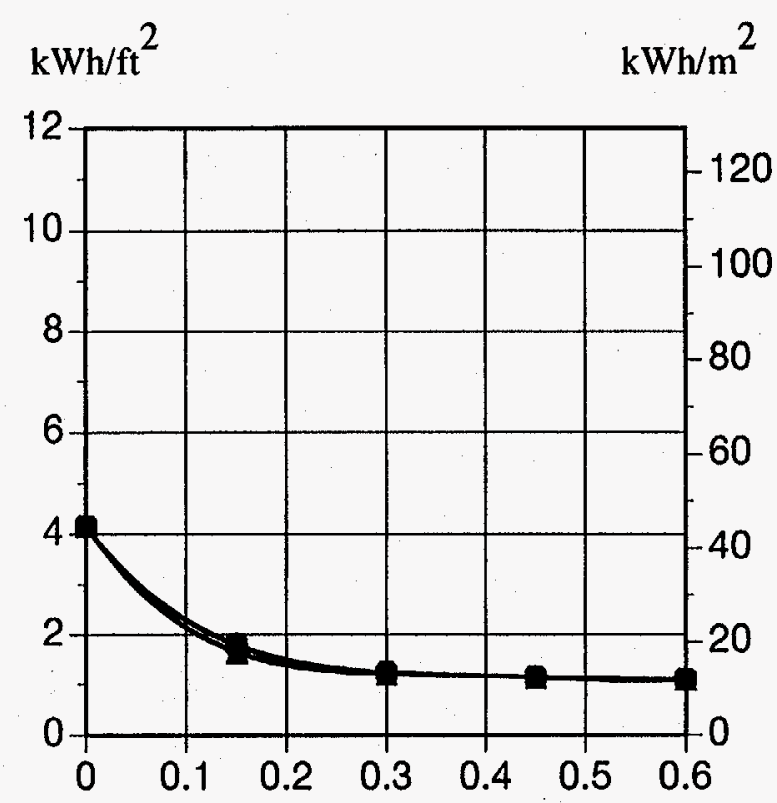

Window-to-Wall Ratio

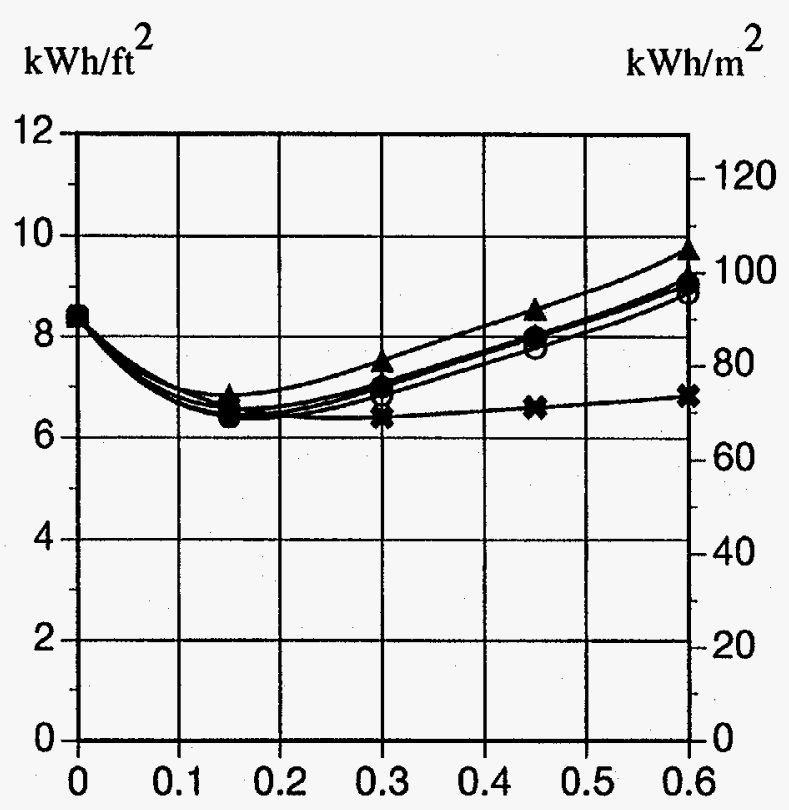

Window-to-Wall Ratio

$\Delta$ EC-Clear Absorptive

$\Delta \quad$ EC-Clear Reflective

- EC-Low-E Absorptive

O EC-Low-E Reflective

$*$ EC-Idealized

Figure 2: Annual electricity consumption due to cooling, fans, and lighting for a westfacing perimeter zone in a prototypical commercial office building module located in Blythe, California. Results are shown for clear and low-E absorptive and reflective electrochromic windows for varying window-to-wall area ratios. The electrochromic windows are controlled to maintain an illuminance level of $50 \mathrm{fc}$ (538 lux). All systems use continuous dimming daylight controls and a lighting power density of $1.5 \mathrm{~W} / \mathrm{ft} 2(16.1 \mathrm{~W} / \mathrm{m} 2)$. 


\section{Cooling + Fan \\ Electricity}

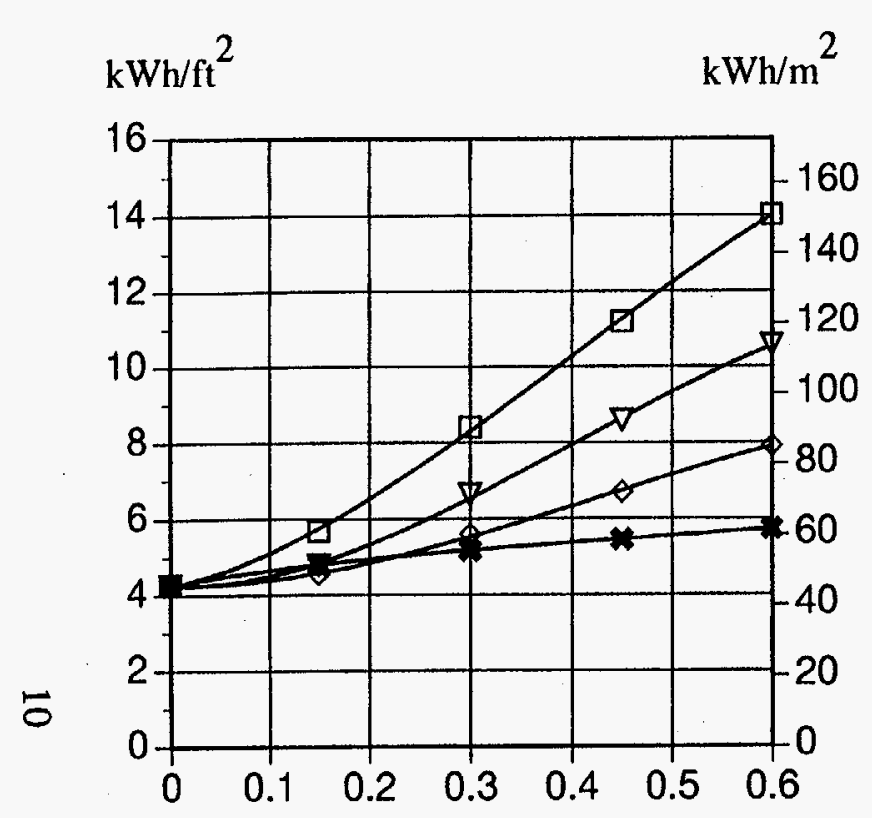

Window-to-Wall Ratio
Lighting

Electricity
Cooling + Fan + Lighting

Electricity

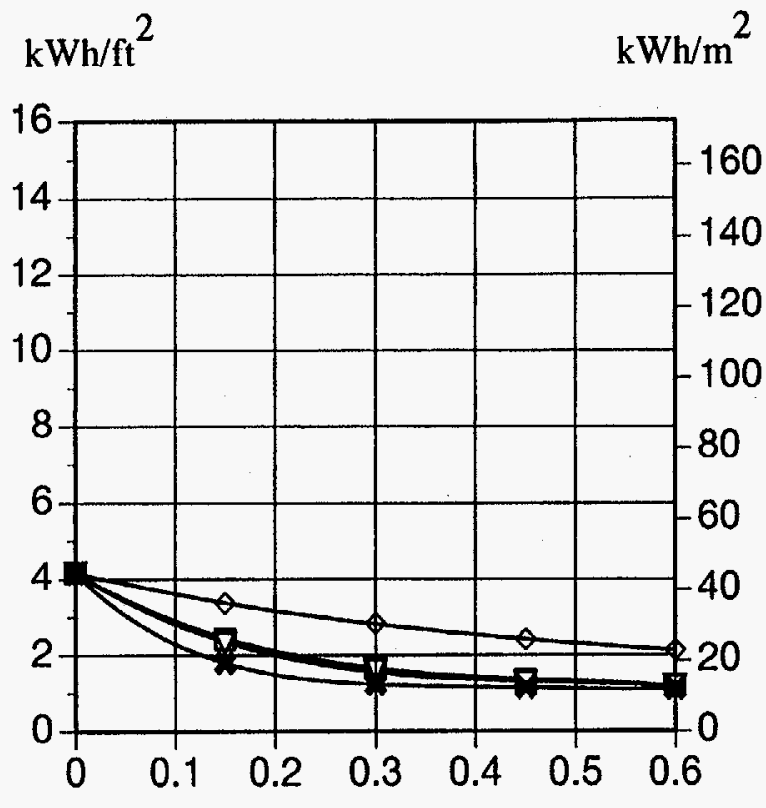

Window-to-Wall Ratio
$\mathrm{kWh} / \mathrm{ft}^{2}$

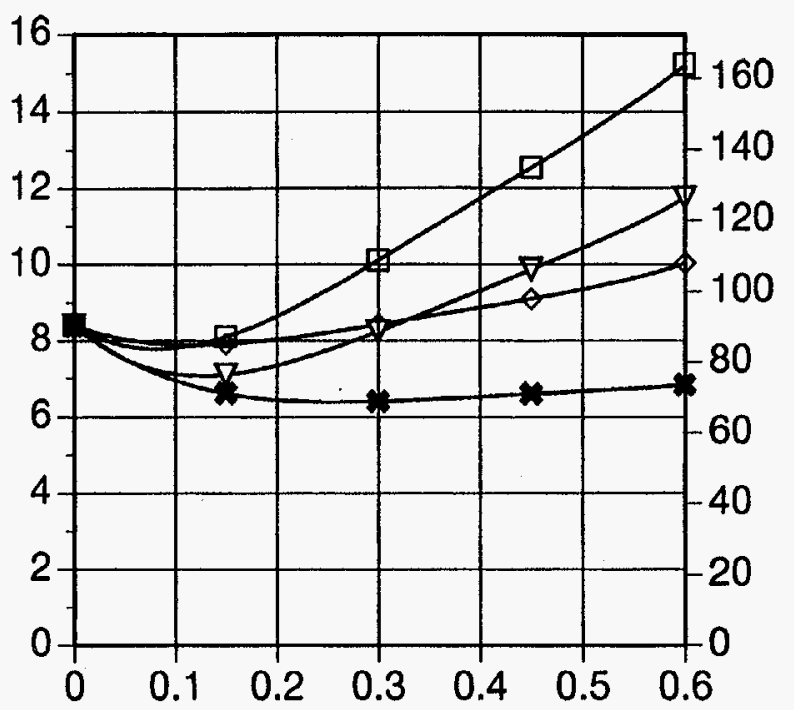

Window-to-Wall Ratio
2

$\mathrm{kWh} / \mathrm{m}^{2}$

Figure 3: Annual electricity consumption due to cooling, fans, and lighting for a westfacing perimeter zone in a prototypical commercial office building module located in Blythe, California. Results are shown for an idealized electrochromic window and several static glazings for varying window-to-wall area ratios. The electrochromic window is controlled to maintain an illuminance level of $50 \mathrm{fc}$ (538 lux). All systems use continuous dimming daylight controls and a lighting power density of $1.5 \mathrm{~W} / \mathrm{ft} 2$ $(16.1 \mathrm{~W} / \mathrm{m}$ 
Daylight Control

Electrochromic Glazings

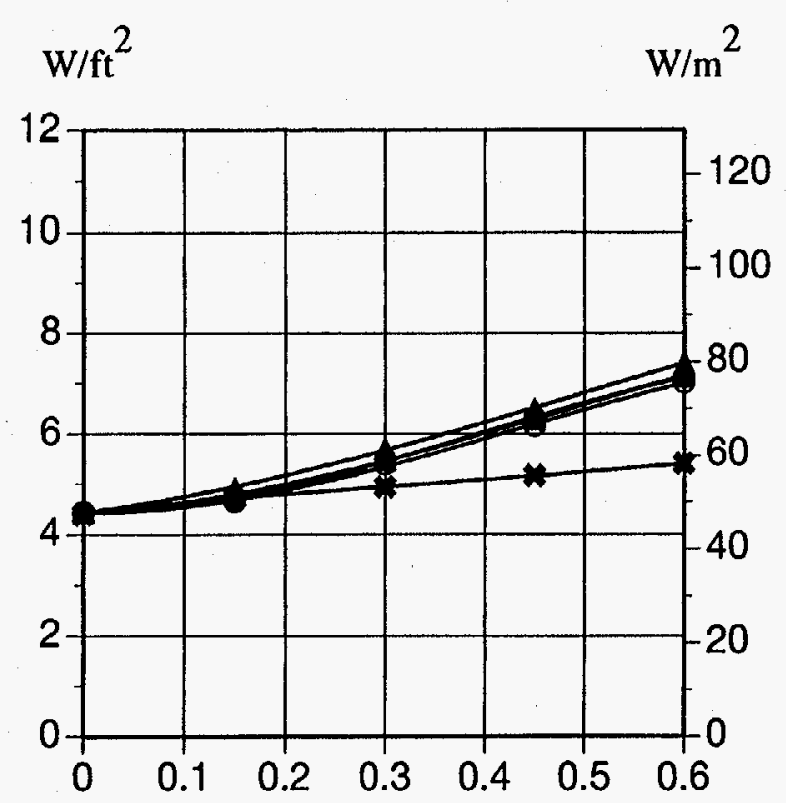

Window-to-Wall Ratio

$\Delta$ EC-Clear Absorptive

$\triangle$ EC-Clear Reflective

- EC-Low-E Absorptive

O EC-Low-E Reflective

* EC-Idealized

\section{Daylight Control}

Standard Glazings

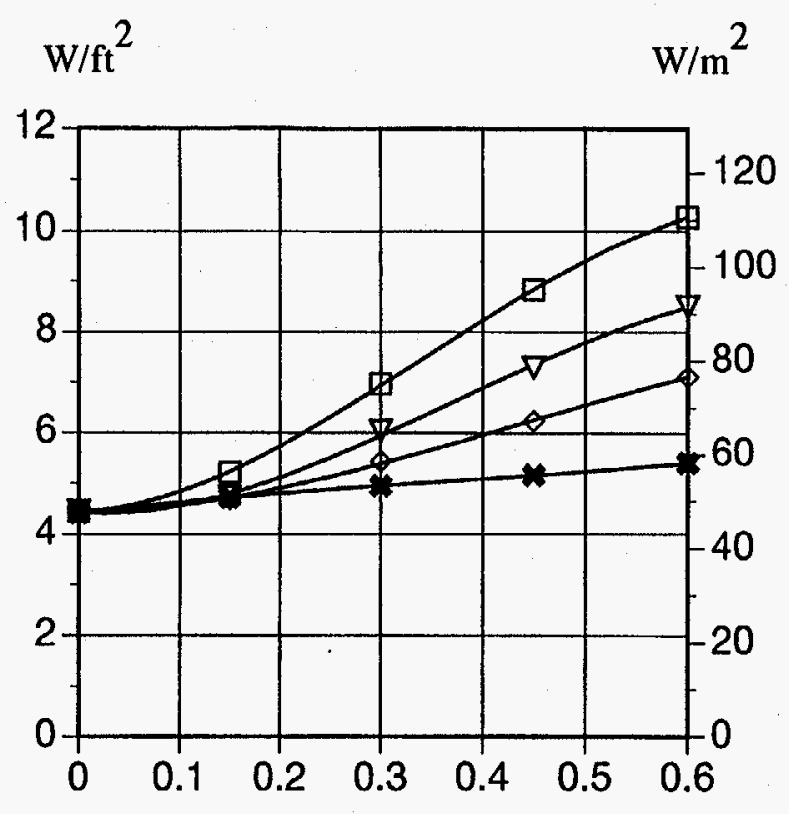

Window-to-Wall Ratio

$\square$ Static-Tinted Grey

$\nabla$ Static-Low E Tint

$\diamond$ Static-Clear Reflective

* EC-Idealized

Figure 4: Peak electricity consumption for a west-facing perimeter zone in a prototypical commercial office building module located in Blythe, California. Results are shown for idealized and clear and low-E absorptive and reflective electrochromic windows electrochromic windows for varying window-to-wall area ratios. The electrochromic windows are controlled to maintain an illuminance level of $50 \mathrm{fc}$ ( $538 \mathrm{lux})$. All systems use continuous dimming daylight controls and a lighting power density of $1.5 \mathrm{~W} / \mathrm{ft} 2(16.1 \mathrm{~W} / \mathrm{m} 2)$. 


\section{Cooling + Fan \\ Electricity}

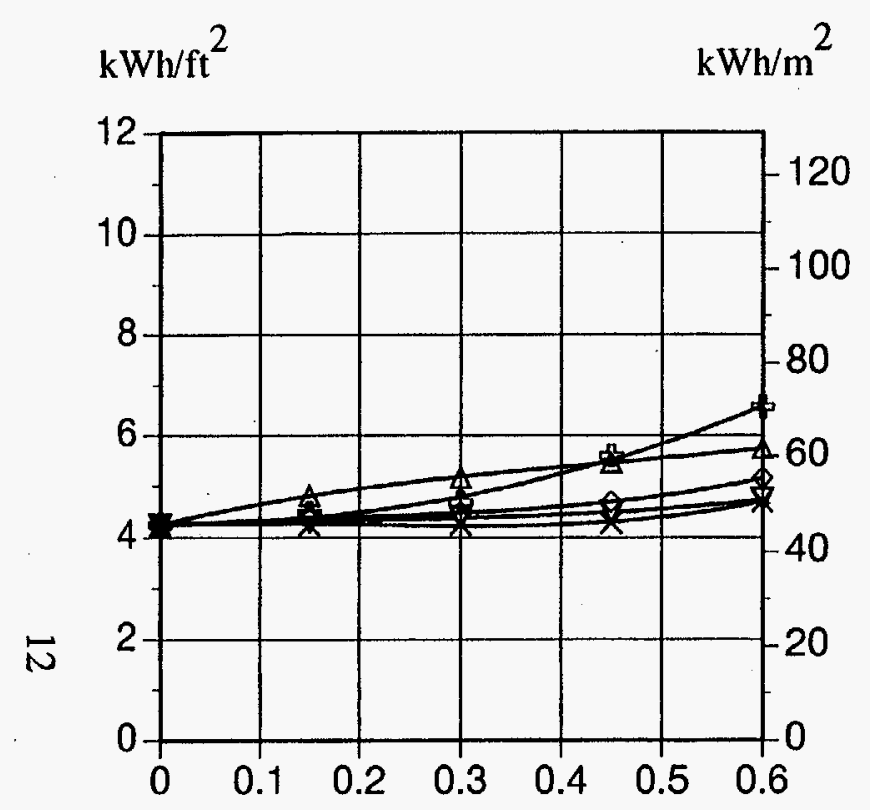

Window-to-Wall Ratio
Lighting

Electricity
Cooling + Fan + Lighting

Electricity

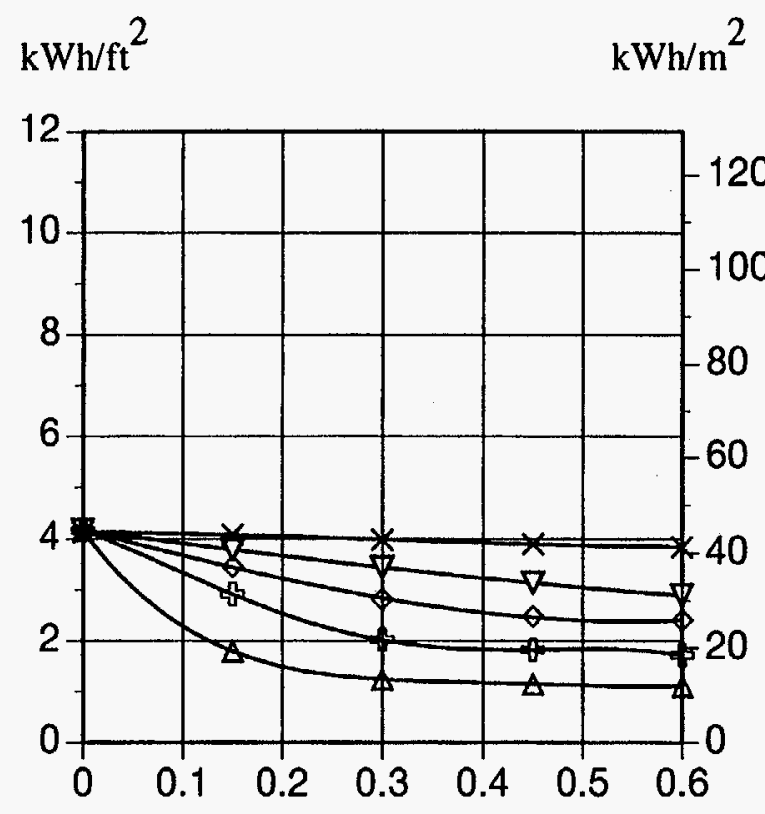

Window-to-Wall Ratio

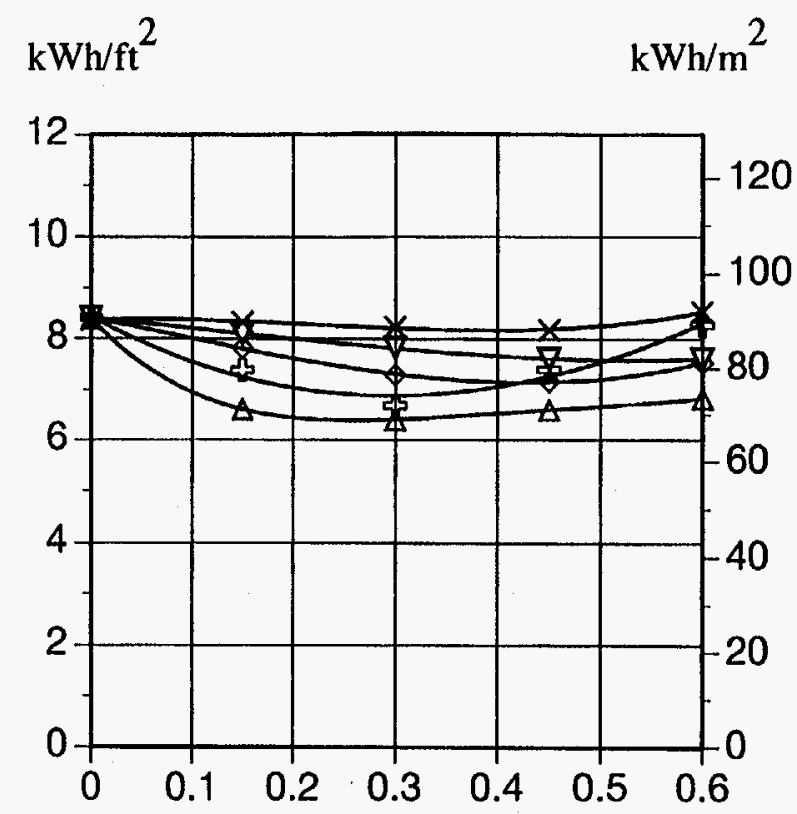

Window-to-Wall Ratio
Figure 5: Annual electricity consumption due to cooling, fans, and lighting for a west-facing perimeter zone in a prototypical commercial office building module located in Blythe, California. Results are shown for an idealized electrochromic window for varying window-to-wall area ratios and electrochromic control strategies. All systems use continuous dimming daylight controls and a lighting power density of $1.5 \mathrm{~W} / \mathrm{ft} 2(16.1 \mathrm{~W} / \mathrm{m} 2)$.
$\Delta \quad$ Daylight Illuminance - $50 \mathrm{fc}(538$ lux $)$

$\nabla \quad$ Incident Total Solar $-20 / 60 \mathrm{~W} / \mathrm{ft} 2(215 / 646 \mathrm{~W} / \mathrm{m} 2)$

$\diamond \quad$ Incident Total Solar - 20/100 W/ft2 (215/1076 W/m2)

t Incident Total Solar $-20 / 200 \mathrm{~W} / \mathrm{ft} 2(215 / 2153 \mathrm{~W} / \mathrm{m} 2)$

$\times$ Space Cooling Load 


\section{Cooling + Fan \\ Electricity}

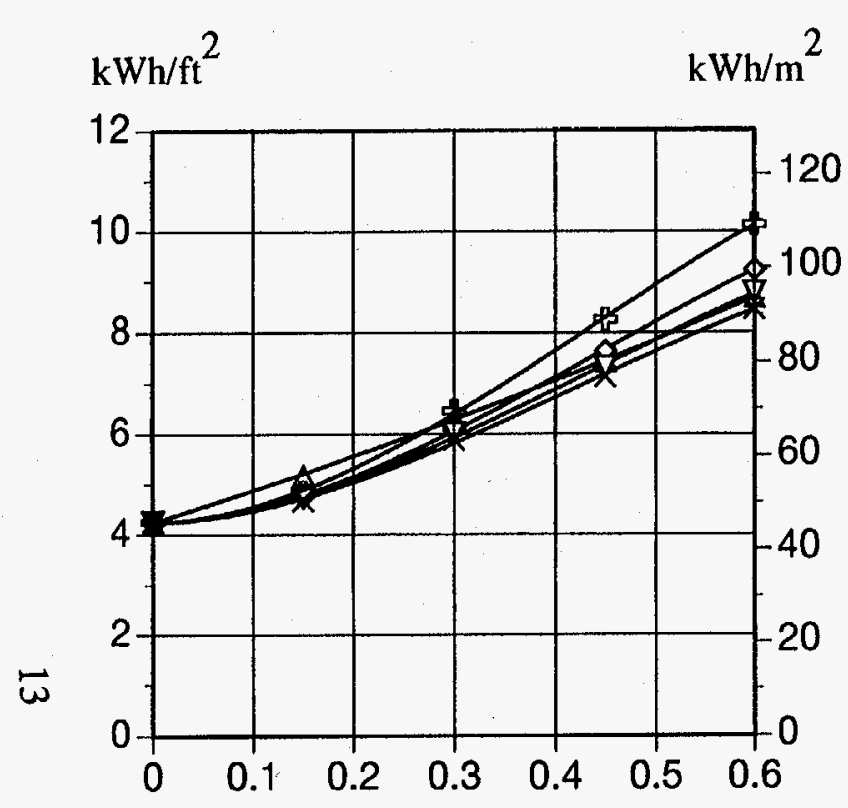

Window-to-Wall Ratio
Lighting

Electricity

\section{Cooling + Fan + Lighting \\ Electricity}

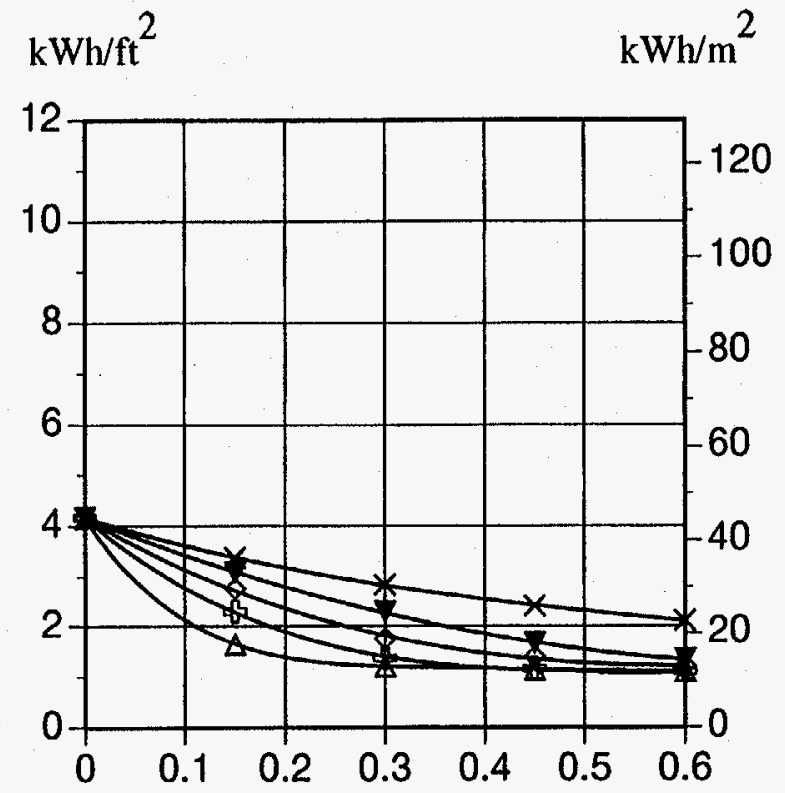

Window-to-Wall Ratio

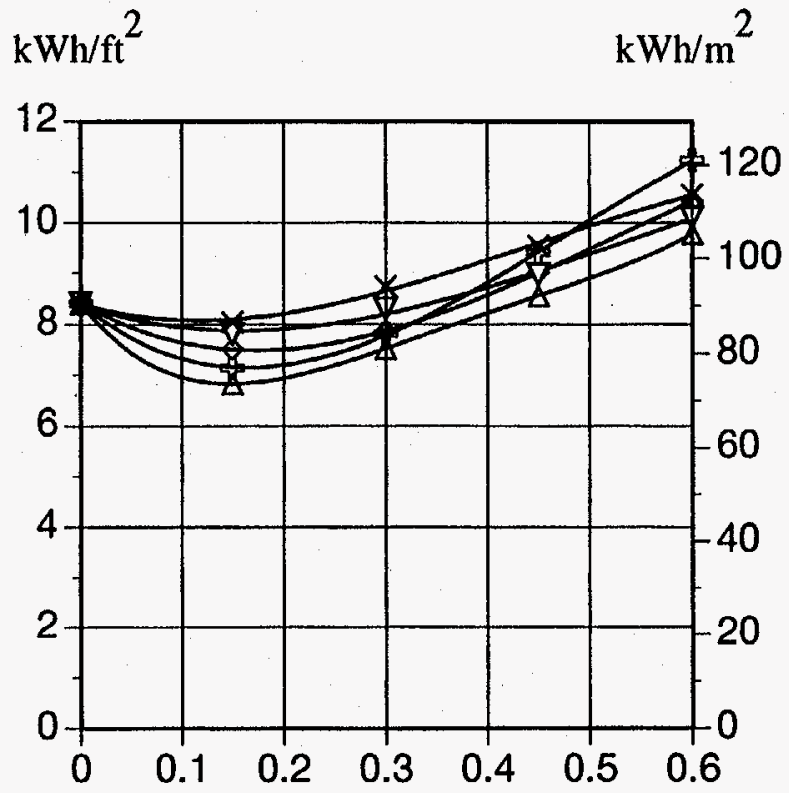

Window-to-Wall Ratio
Figure 6: Annual electricity consumption due to cooling, fans, and lighting for a west-facing perimeter zone in a prototypical commercial office building module located in Blythe, California. Results are shown for a clear-absorptive electrochromic window for varying window-towall area ratios and electrochromic control strategies. All systems use continuous dimming daylight controls and a lighting power density of $1.5 \mathrm{~W} / \mathrm{ft} 2(16.1 \mathrm{~W} / \mathrm{m} 2)$.
$\Delta \quad$ Daylight Illuminance $-50 \mathrm{fc}(538 \mathrm{lux})$

$\nabla$ Incident Total Solar - 20/60 W/ft2 (215/646 W/m2)

$\diamond \quad$ Incident Total Solar - 20/100 W/ft2 (215/1076 W/m2)

\& Incident Total Solar - 20/200 W/ft2 (215/2153 W/m2)

$\times \quad$ Space Cooling Load 


\section{Cooling + Fan \\ Electricity}

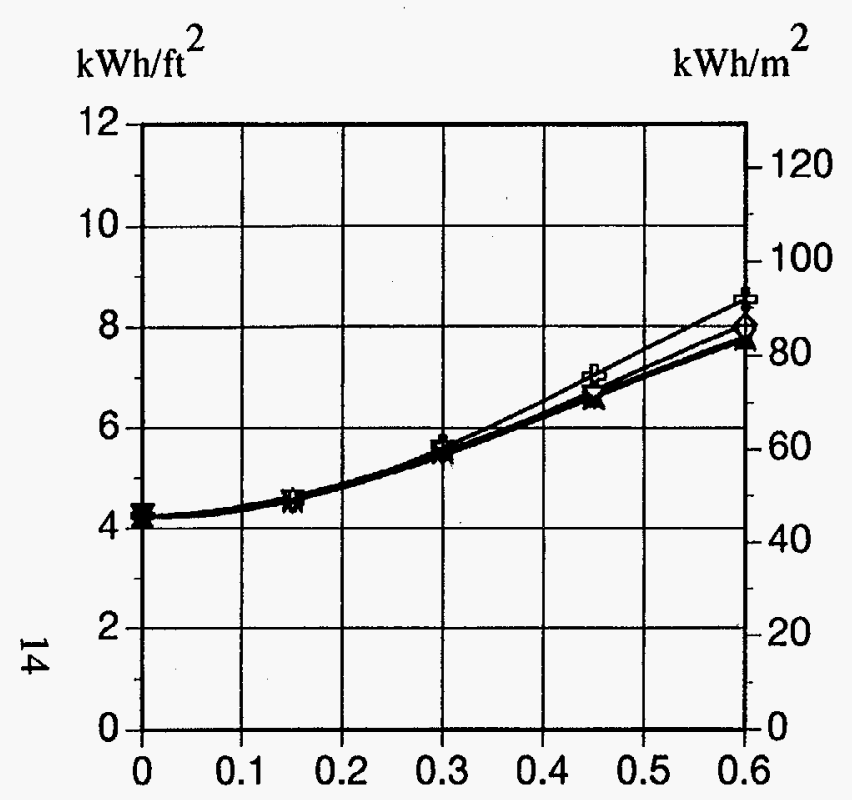

Window-to-Wall Ratio
Lighting

Electricity

\section{Cooling + Fan + Lighting Electricity}

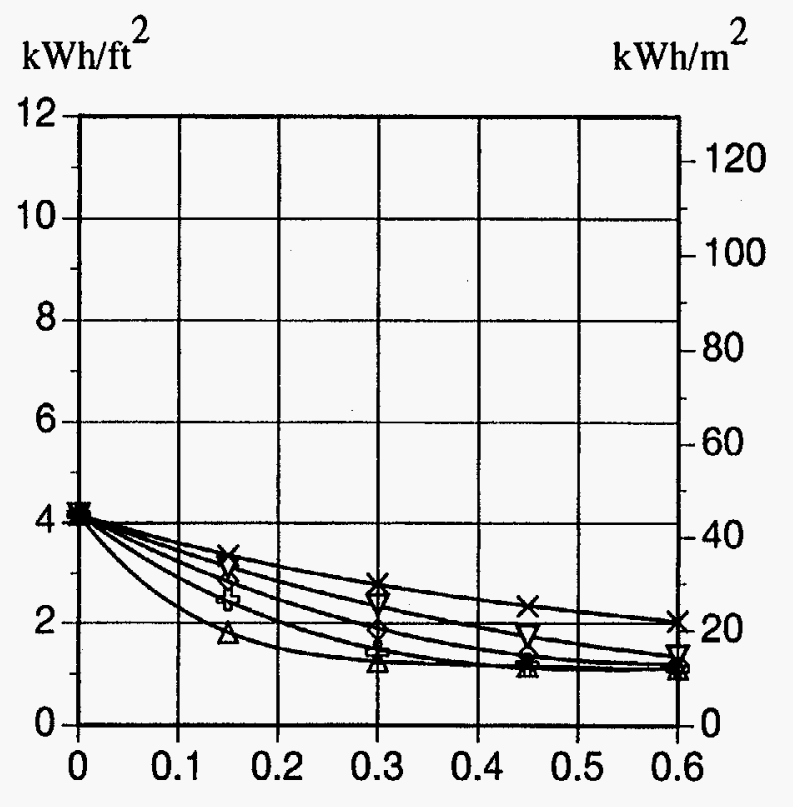

Window-to-Wall Ratio

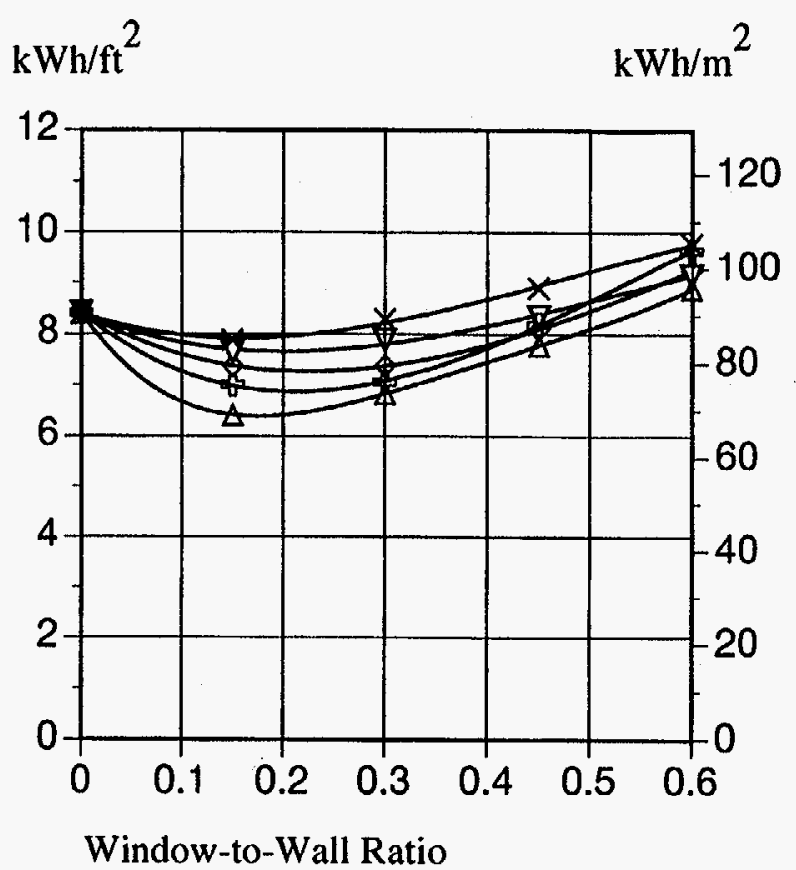

Figure 7: Annual electricity consumption due to cooling, fans, and lighting for a west-facing perimeter zone in a prototypical commercial office building module located in Blythe, California. Results are shown for a low-E reflective electrochromic window for varying window-towall area ratios and electrochromic control strategies. All systems use continuous dimming daylight controls and a lighting power density of $1.5 \mathrm{~W} / \mathrm{ft} 2(16.1 \mathrm{~W} / \mathrm{m} 2)$.
$\Delta \quad$ Daylight Illuminance $-50 \mathrm{fc}$ (538 lux)

$\nabla \quad$ Incident Total Solar - 20/60 W/ft2 $(215 / 646 \mathrm{~W} / \mathrm{m} 2)$

$\diamond \quad$ Incident Total Solar - 20/100 W/ft2 (215/1076 W/m2)

↔Incident Total Solar - 20/200 W/ft2 (215/2153 W/m2)

$\times$ Space Cooling Load 
Idealized

Electrochromic Glazing
Clear Absorptive Electrochromic Glazing
Low-E Reflective Electrochromic Glazing

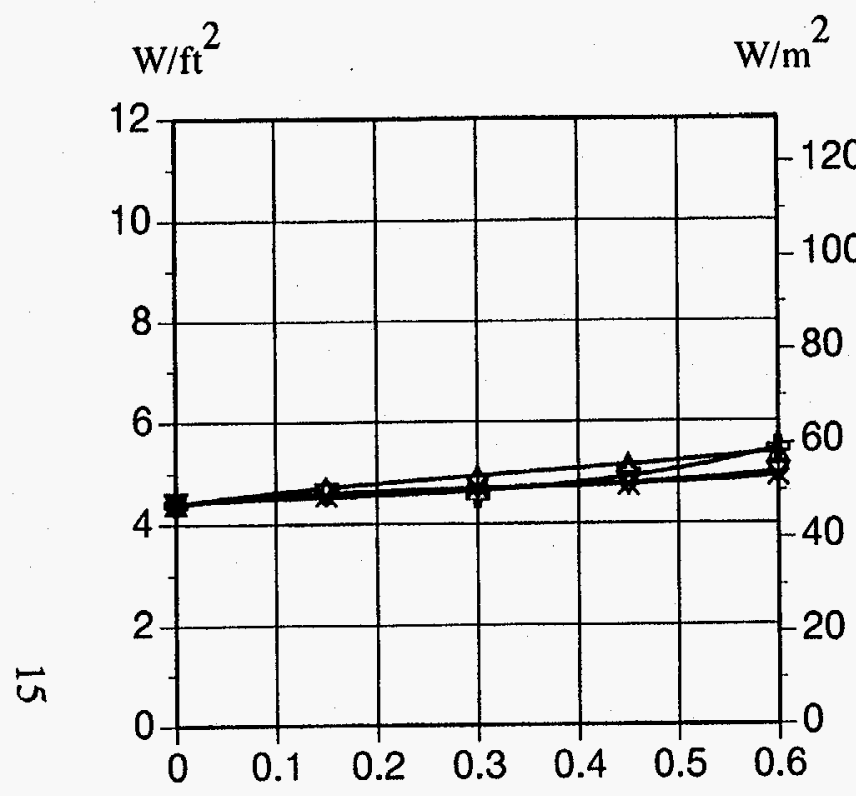

Window-to-Wall Ratio

$$
\mathrm{W} / \mathrm{ft}^{2}
$$

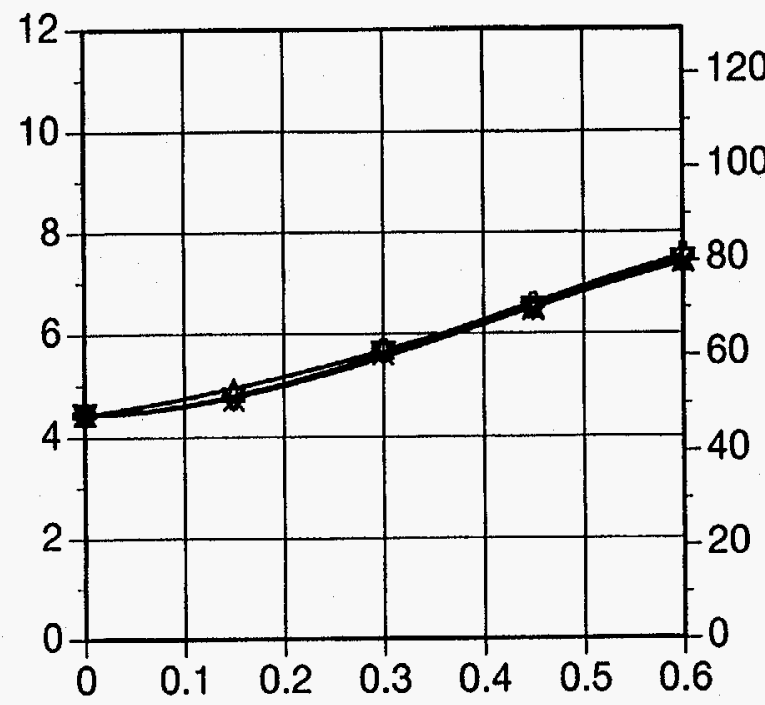

Window-to-Wall Ratio

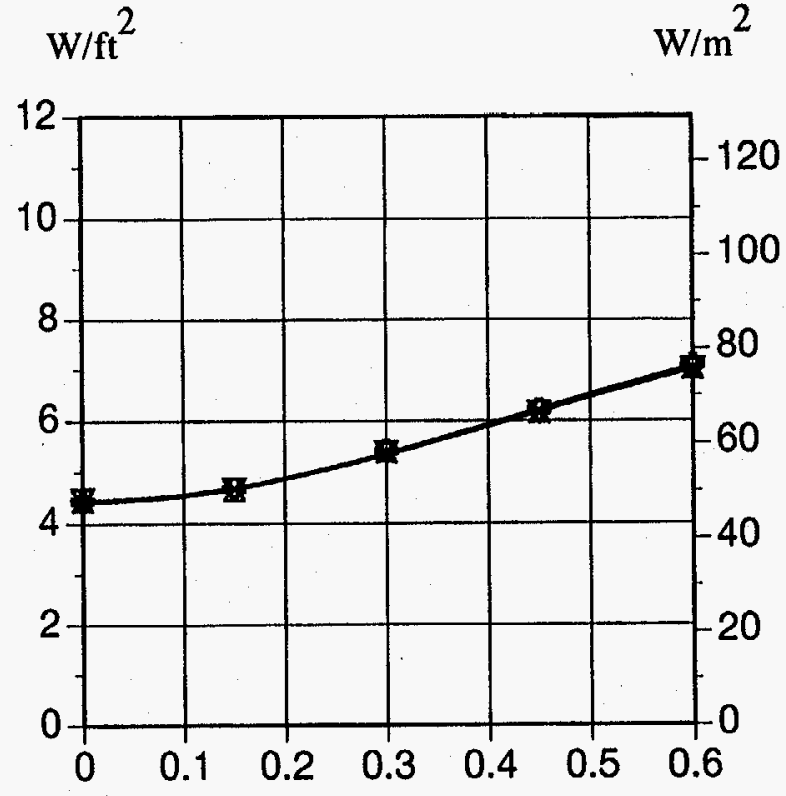

Window-to-Wall Ratio

Figure 8: Peak electricity consumption for a west-facing perimeter zone in a prototypical commercial office building module located in Blythe,

California. Results are shown for an idealized, real clear-absorptive, and low-

$E$ reflective electrochromic windows for varying window-to-wall area ratios and electrochromic control strategies. All systems use continuous dimming daylight controls and a lighting power density of $1.5 \mathrm{~W} / \mathrm{ft} 2$

(16.1 W/m2).

$\Delta \quad$ Daylight Illuminance $-50 \mathrm{fc}(538 \mathrm{lux})$

$\nabla \quad$ Incident Total Solar - 20/60 W/ft2 (215/646 W/m2)

$\diamond$ Incident Total Solar - 20/100 W/ft2 (215/1076 W/m2

$\&$ Incident Total Solar $-20 / 200 \mathrm{~W} / \mathrm{ft} 2(215 / 2153 \mathrm{~W} / \mathrm{m} 2$.

$\times$ Space Cooling Load 